\title{
Genetic linkage analysis in hereditary non-polyposis colon cancer syndrome
}

\author{
Nicola J Froggatt, Jane Koch, Rhodri Davies, D Gareth R Evans, Andrew Clamp, \\ Oliver W J Quarrell, Jean Weissenbach, Shirley V Hodgson, Bruce A J Ponder, \\ David E Barton, Eamonn R Maher
}

Cambridge University Department of Pathology, Box 134, Addenbrooke's Hospital, Hills Road, Cambridge CB2 2QQ, UK

N J Froggatt

J Koch

A Clamp

E R Maher

Molecular Genetics Laboratory,

Addenbrooke's

Hospital, Cambridge,

UK

N J Froggatt

A Clamp

D E Barton

\section{Department of}

Medical Genetics,

St Mary's Hospital,

Manchester, UK

$R$ Davies

D G R Evans

Centre for Human Genetics, Sheffield, UK

O W J Quarrell

Laboratoire Genethon, 1 rue de

1'Internationale, Evry

91002, France

$\mathrm{J}$ Weissenbach

Medical Genetics, Guy's Hospital,

London, UK

$S$ V Hodgson

CRC Human Cancer Genetics Group, Cambridge University Department of Pathology, UK

B A J Ponder

Correspondence to: Dr Maher.

Received 18 October 1994 Revised version accepted fo publication 5 January 1995

\begin{abstract}
Hereditary Non-polyposis Colon Cancer Syndrome (HNPCC) is the most common cause of familial colorectal cancer. Molecular genetic studies of HNPCC have shown evidence of locus heterogeneity, and mutations in four genes (hMSH2, hMLH1, hPMS1, and hPMS2) which encode components of the mismatch enzyme repair system may cause HNPCC. To determine the extent and nature of locus heterogeneity in HNPCC, we performed genetic linkage studies in 14 HNPCC families from eastern and north-western England. Linkage to hMLH1 was excluded in six families, each of which were likely to be linked to hMSH2 (lod score $>1.0$ in each family and total lod score for all six families $=7 \cdot 64$ ). Linkage to hMSH2 was excluded in three families, each of which were likely to be linked to hMLH1 (lod score $>1.0$ in each family and total lod score at hMLH1 for all three families $=3.93$ ). In the remaining five families linkage to hMSH2 or hMLH1 could not be excluded. These results confirm locus heterogeneity in HNPCC and suggest that, in the population studied, most large families with HNPCC will have mutations in hMSH2 or hMLH1. We did not detect any correlation between clinical phenotype and the genetic linkage results, but a Muir-Torre syndrome family excluded from linkage to $h M L H 1$ was likely to be linked to hMSH2 and showed microsatellite instability in a tumour from an affected relative.
\end{abstract}

(f Med Genet 1995;32:352-357)

It is estimated that up to $10 \%$ of all cases of colorectal cancer occur in genetically predisposed people. The importance of inherited susceptibility is greater in early onset cases such that people with a first degree relative with colorectal cancer diagnosed $<45$ years have a five-fold increase in lifetime risk of colorectal cancer. ${ }^{1}$ A small proportion of familial colorectal cancer is caused by familial adenomatous polyposis coli (FAPC), a dominantly inherited disorder with an incidence of 1 in 8000 caused by mutations in the APC gene on chromosome $5 \mathrm{q} 21 .^{2-5}$ FAPC is characterised by the development of numerous $(>100)$ colonic polyps in the second and third decades, and colorectal carcinoma is almost inevitable unless colectomy is performed. A much larger proportion (up to $10 \%$ ) of cases are thought to be caused by hereditary non-polyposis colon cancer syndrome (HNPCC). This disorder is characterised by a dominantly inherited predisposition to early onset colon cancer (mean 46 years). ${ }^{6-8}$ Affected patients develop multiple colorectal cancers, but florid colonic polyposis is not a feature. In many cases there is also an increased risk of extracolonic cancers such as uterine, ovarian, and ureteric. Clinical heterogeneity is well recognised in HNPCC, and families have been subdivided according to the presence or absence of extracolonic cancers (Lynch family cancer syndromes types 2 and 1 respectively), or associated skin lesions (MuirTorre syndrome). ${ }^{7-9}$

Families with a classical HNPCC phenotype do not show linkage to the APC gene, ${ }^{10}$ but Peltomaki et $a l^{11}$ mapped a HNPCC locus to chromosome 2 p16 in 1993. In addition, these investigators also detected evidence of widespread instability of simple DNA repeat polymorphisms in tumours from HNPCC patients suggesting that HNPCC can result from defects in the mechanisms responsible for maintaining the fidelity of DNA replication. ${ }^{12}$ Subsequent studies identified the chromosome 2p16 HNPCC gene (hMSH2) as the human homologue of the bacterial mutS. ${ }^{1314}$ Further studies have shown that mutations in three other genes (hMLH1 in chromosome 3p21, hPMS1 in chromosome $2 \mathrm{q} 31-32$, and hPMS 2 in $7 \mathrm{p} 22$ ) which encode components of the mismatch repair enzyme complex may also produce HNPCC. ${ }^{15-17}$ Despite the rapid progress in the identification of HNPCC genes, the molecular genetics of HNPCC have been investigated in relatively few families. The initial study which successfully mapped a HNPCC locus to $2 \mathrm{p} 16$ included 14 kindreds from Europe, North America, and New Zealand and it was estimated that approximately $50 \%$ of HNPCC families were linked to hMSH2. ${ }^{12}{ }^{13}$ However, most Finnish families are not linked to hMSH2 and the majority appear to be caused by mutations in hMLH1. ${ }^{18}$ Clearly the optimum approach for the molecular genetic diagnosis of HNPCC will depend on the relative importance of the four candidate genes in the relevant population. We have investigated the nature and extent of locus heterogeneity in HNPCC by performing genetic linkage studies in 14 families ascertained from eastern and north western England. 
A

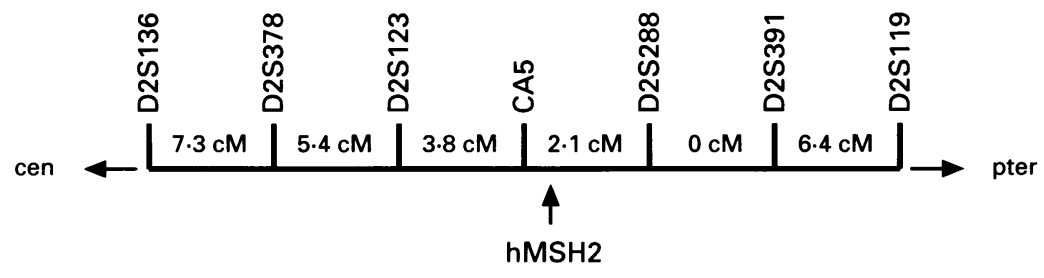

B

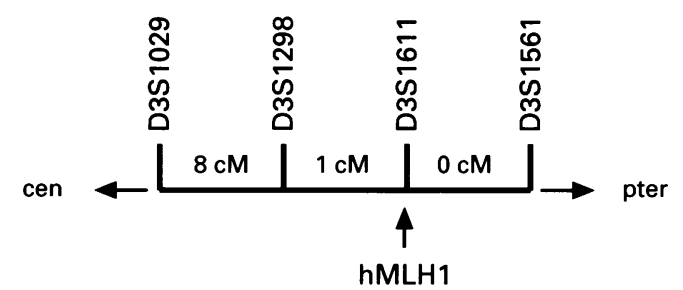

Figure 1 Genetic maps of chromosome $2 p 16$ (A) and $3 p 21$ (B) showing the positions of $h M S H 2$ and $h M L H 1$ and marker loci investigated.

\section{Materials and methods}

PATIENTS

One hundred and sixty eight subjects ( 45 affected patients and 123 at risk relatives and spouses) from 14 families with HNPCC were genotyped with microsatellite markers linked to hMSH2 (D2S119, D2S391, D2S288, CA5, D2S123, D2S378, D2S136) ${ }^{141920}$ and hMLH1 (D3S1029, D3S1298, D3S1561, and D3S1611). ${ }^{18-21}$ Families were ascertained from East Anglia and north west England and were of British or Irish origin. All families satisfied the Amsterdam criteria for the diagnosis of HNPCC: at least three relatives with colorectal cancer in two or more generations, with at least one patient diagnosed aged $<50$ years. ${ }^{22}$ Noncolonic cancers known to be associated with the Lynch 2 phenotype (uterus, ovary, and ureter) occurred in seven families. A diagnosis of Muir-Torre syndrome was made in one kindred (C004). ${ }^{23-25}$ No families had evidence of classical or attenuated adenomatous polyposis coli. ${ }^{26}$ Family members were considered affected if they developed (1) colorectal cancer, (2) an extraintestinal cancer typical of HNPCC (uterine or ovarian), or (3) multiple (2 to 20) adenomatous polyps aged $<40$ years.

\section{DNA ANALYSIS}

High molecular weight DNA was isolated from peripheral blood or lymphoblastoid cell lines by conventional methods. DNA was amplified by the polymerase chain reaction under the appropriate conditions and the alleles resolved on a $6 \%$ polyacrylamide $/ 6 \mathrm{~mol} / 1$ urea sequencing gel as described previously. ${ }^{2728}$ Evidence of microsatellite instability was sought in tumours from affected members of five families using five microsatellite polymorphisms: D3S1007, D3S1076, ${ }^{21}$ D5S346, ${ }^{29}$ D17S588, and CA5 on chromosome 2 p. ${ }^{14}$ DNA was extracted from $15 \mu \mathrm{m}$ sections from paraffin embedded normal and tumour tissue, according to the following procedure, adapted from Smith et $a l^{30}$ : one section was placed into $300 \mu \mathrm{lex}$ traction buffer $(50 \mathrm{mmol} / 1 \mathrm{KCl}, 10 \mathrm{mmol} / \mathrm{l}$ Tris-Cl pH 8.3, $2.5 \mathrm{mmol} / 1 \mathrm{MgCl}_{2}, 0.1 \mathrm{mg} / \mathrm{ml}$ gelatin, $0.45 \%$ Nonidet $\mathrm{P} 40,0.45 \%$ Tween 20), $200 \mu \mathrm{g}$ Pronase $^{\mathrm{TM}}$ (Boehringer Mannheim UK, Lewes, UK) added, and the extraction incubated at $40^{\circ} \mathrm{C}$ for seven days. Chelex ${ }^{\mathrm{TM}}$ resin (BioRad, Hemel Hempstead, UK) was added to a final concentration of $1.67 \%$ from a well mixed $5 \%$ stock solution, and the extraction incubated at $56^{\circ} \mathrm{C}$ for 30 minutes. After enzyme inactivation by boiling for 10 minutes, the extraction was microcentrifuged for 30 seconds at $13000 \mathrm{rpm}$ and 1 to $5 \mu \mathrm{l}$ was used for each amplification. The finding of microsatellite instability at two or more loci was considered significant. ${ }^{31}$

\section{GENETIC LINKAGE ANALYSIS}

LIPED and LINKAGE computer programmes were used for two point and multipoint linkage analysis. Age dependent penetrance values were as follows: age $<30$ years $=0 \cdot 00,30-45$ years $=0 \cdot 15,46-60$ years $=0 \cdot 70,>60$ years $=$ $0 \cdot 90$. The risk of an at risk person coincidentally developing sporadic cancer of the HNPCC type was estimated at 0.01 at age $<45$ years, 0.03 aged $45-60$ years, 0.05 aged $>60$ years, and 0.001 for the occurrence of multiple primary tumours (EUROFAP HNPCC collaboration, personal communication, Professor $\mathrm{T}$ Bishop). The risk of multiple adenomatous colonic polyps $<40$ years in a non-gene carrier was taken as $0 \cdot 03$. Each microsatellite marker was analysed assuming five alleles of equal frequencies. The pre-existing map order and distances (recombination fractions) were derived from published studies ${ }^{14-18}$ and is shown in fig 1 . For each family a haplotype was constructed for the chromosome $2 \mathrm{p} 16$ and $3 \mathrm{p} 21$ markers analysed and lod scores at hMSH2 and hMLH1 were calculated using the MLINK program and results from informative flanking markers.

Table 1 Two point lod scores at loci on chromosome $2 p$ and $3 p$ for 14 HNPCC families

\begin{tabular}{|c|c|c|c|c|c|c|c|}
\hline & \multicolumn{7}{|c|}{ Recombination fraction } \\
\hline & $0 \cdot 0$ & 0.01 & 0.05 & $0 \cdot 10$ & $0 \cdot 20$ & $0 \cdot 30$ & $0 \cdot 40$ \\
\hline $\begin{array}{l}\text { D2S119 } \\
\text { D2S391 } \\
\text { D2S288 } \\
\text { CA5 } \\
\text { D2S123 } \\
\text { D2S378 } \\
\text { D2S136 } \\
\text { D3S1029 } \\
\text { D3S1298 } \\
\text { D3S1561 } \\
\text { D3S } 1611\end{array}$ & $\begin{array}{c}-10.97 \\
-7.79 \\
-1.79 \\
-5.25 \\
2.28 \\
-3.16 \\
-3.24 \\
-12.8 \\
-13.69 \\
-3.27 \\
-6.07\end{array}$ & $\begin{array}{r}-7 \cdot 25 \\
-5 \cdot 18 \\
-1.45 \\
-3.99 \\
2.53 \\
-1 \cdot 12 \\
-1.91 \\
-8.32 \\
-9.47 \\
-1.57 \\
-3.43\end{array}$ & $\begin{array}{r}-3.77 \\
-1.43 \\
-0.79 \\
-2.15 \\
2.75 \\
1.38 \\
-0.15 \\
-3.82 \\
-5.05 \\
-0.51 \\
-1.44\end{array}$ & $\begin{array}{r}-2 \cdot 02 \\
0 \cdot 26 \\
-0.41 \\
-1 \cdot 20 \\
2 \cdot 63 \\
2 \cdot 22 \\
0.64 \\
-1 \cdot 75 \\
-2.75 \\
-0.02 \\
-0.65\end{array}$ & $\begin{array}{r}-0.52 \\
1.18 \\
-0.1 \\
-0.43 \\
1.96 \\
2.17 \\
0.98 \\
-0.25 \\
-0.80 \\
0.28 \\
-0.13\end{array}$ & $\begin{array}{r}-0.03 \\
0.91 \\
-0.01 \\
-0.17 \\
1.09 \\
1.36 \\
0.71 \\
0.08 \\
-0.18 \\
0.23 \\
-0.04\end{array}$ & $\begin{array}{r}0.04 \\
0.31 \\
0.01 \\
-0.08 \\
0.31 \\
0.45 \\
0.26 \\
0.03 \\
-0.05 \\
0.09 \\
-0.04\end{array}$ \\
\hline
\end{tabular}




\section{Results}

GENETIC LINKAGE ANALYSIS

Significant evidence of linkage (total lod score $>3.0$ for all 14 families) was not detected at any of the 11 loci investigated (table 1). However, inspection of marker haplotypes and of individual family lod scores was consistent with locus heterogeneity. Formal heterogeneity analysis provided clear evidence for locus heterogeneity with linkage to hMSH2 (evidence that some families linked to hMSH $2, \chi^{2}=32 \cdot 1$, $\mathrm{p}<2 \times 10^{-8}$ ) and hMLH1 (evidence that some families linked to hMLH1, $\chi^{2}=21.9$, $\left.\mathrm{p}<3 \times 10^{-6}\right)$. On the basis of these results the families were divided into three groups (table 2).

Group A. Exclusion of linkage to hMLH1 and probable linkage to $h M S H 2$

Linkage to hMLH1 was excluded in six families (C001, C002, C003, C004, C015, C016). In each of these haplotype analysis was consistent with linkage to $\mathrm{hMSH} 2$ and the total lod score at hMSH2 for all six families was 7.64 at $\theta=$ 0 (fig 2). However, although each of these families was likely to be linked to hMSH2, no single family provided a lod score $>3$.

Group B. Exclusion of linkage to hMSH2 and probable linkage to $h M L H 1$

Linkage to hMSH2 could be excluded in three families (C009, C012, C014), and in each of these families haplotype analysis was consistent with linkage to hMLH1. The total lod score at hMLH1 for these three families was 3.93 although no single family gave a lod score $>3$. Nevertheless each of the families excluded from linkage to hMSH2 was likely to be linked to hMLHl (fig 3).

Group C. Not excluded from linkage to hMSH2 or $h M L H 1$

Five families could not be excluded from linkage to hMSH2 or hMLH1 and did not give convincing evidence of linkage to $\mathrm{hMSH} 2$ or
D2S391

$\mathrm{D} 2 \mathrm{~S} 123$

D2S378

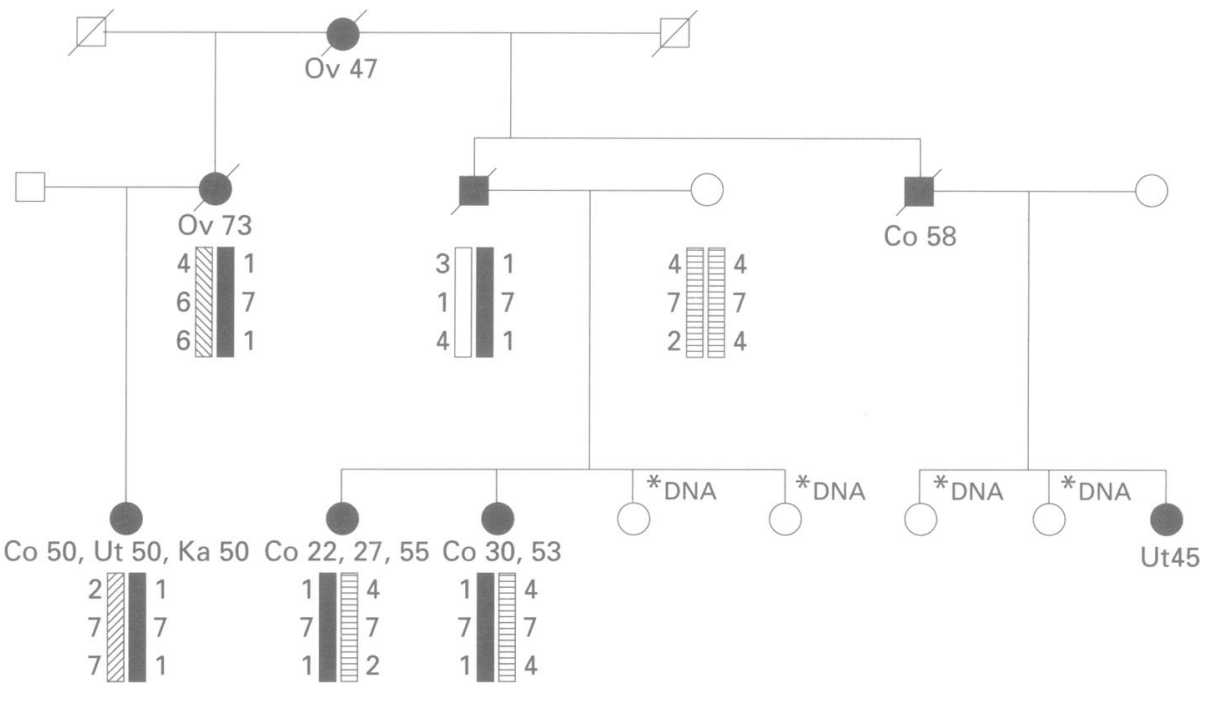

D3S1611

D3S1298

D3S1029

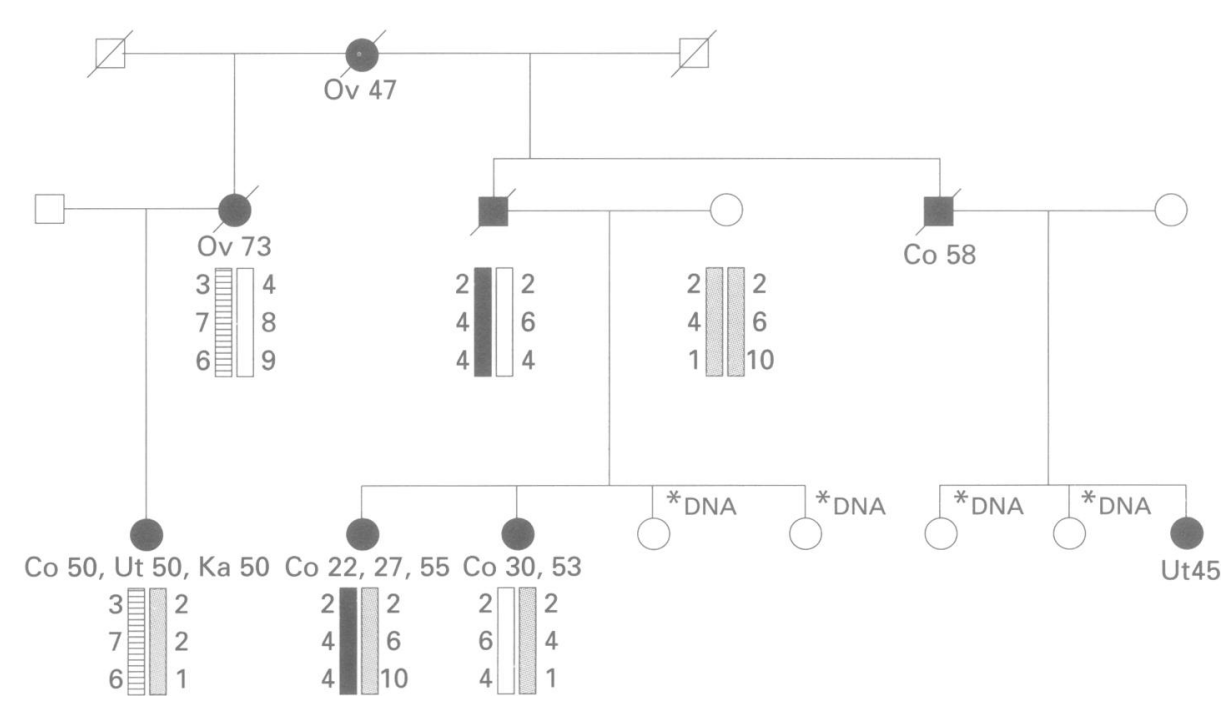

Figure 2 Pedigree details, cancer diagnosis, and examples of haplotyping construction for loci linked to hMSH2 (top panel) and hMLH1 (lower panel) in family C004. Results were obtained for unaffected subjects marked ${ }^{*}$, but are not panel) and hMLH1 (lower panel) in family C004. Results were obtained for unaffected subjects marked ${ }^{*}$, but are not
given to preserve confidentiality. Under each symbol is listed the confirmed diagnosis (Co = colorectal cancer, Ut=uterine cancer, Ka=Keratoacanthoma, Ov=ovarian cancer) and age at diagnosis. 
hMLH1. There was no evidence for a third HNPCC locus both by formal heterogeneity testing and by direct inspection of $\mathrm{hMSH} 2$ and hMLH1 haplotypes.

\section{CLINICAL PHENOTYPE AND GENETIC LINKAGE} ANALYSIS

There was no apparent correlation between the results of genetic linkage analysis and clinical phenotype. A Lynch 1 phenotype (no extracolonic cancers) was found in two families in group $\mathrm{A}$, two families in group $\mathrm{B}$, and two

families in group C. One family (C004) in group A had a Muir-Torre syndrome phenotype, and a Lynch 2 phenotype (presence of uterine, ovarian, or ureteric cancer) occurred in three families in group A, one in group B, and three in group $\mathrm{C}$. The mean age (SD) of colorectal cancer in affected subjects was similar in each of three groups: group A, 46.3 (SD $10 \cdot 3$ ) years; group $\mathrm{B}, 44 \cdot 3$ (SD 8.8) years; and group $\mathrm{C}, 44.8(\mathrm{SD} 6 \cdot 6)$ years.

REPLICATION ERRORS IN COLORECTAL CANCERS

Replication errors were detected at two or more loci in colorectal cancers from the five families
D2S391

D2S288

CA5

D2S123

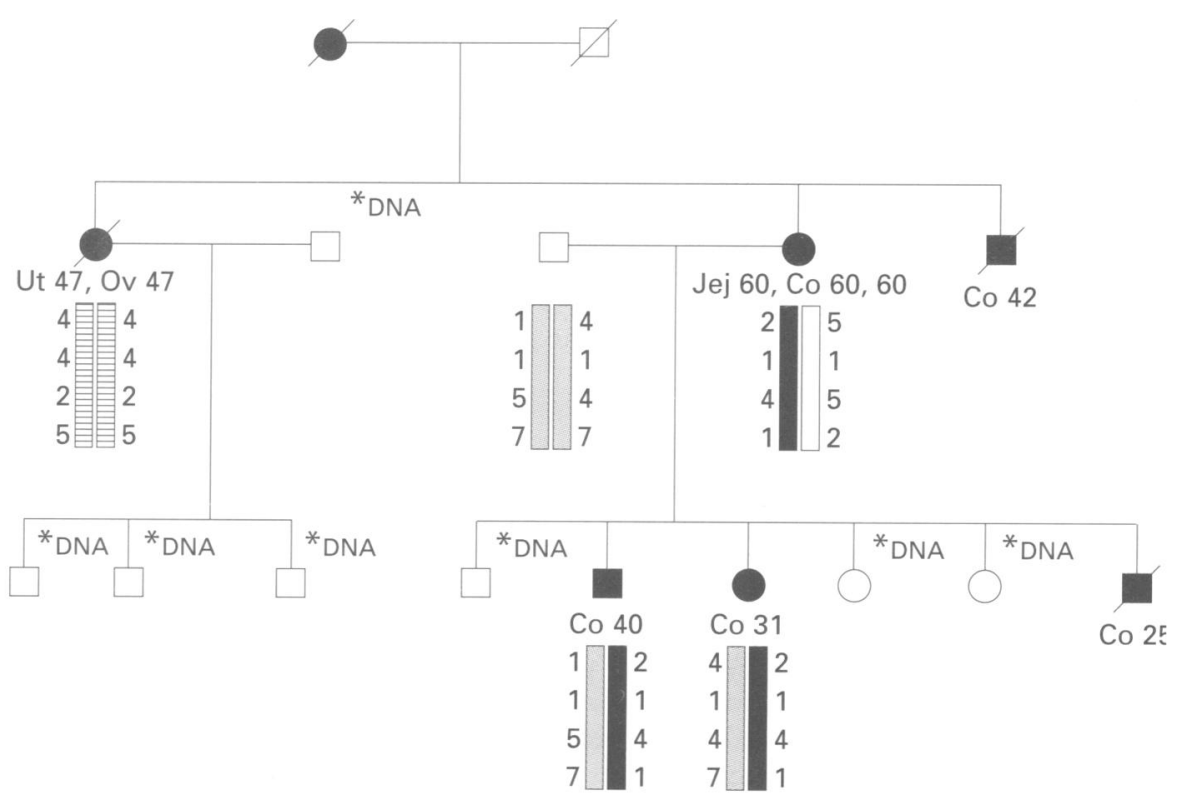

D3S1561

D3S1611

D3S1298

D3S1029

Figure 3 Pedigree details, cancer diagnosis, and examples of haplotyping construction for loci linked to hMSH2 (top panel) and hMLH1 (lower panel) in family C012. Results were obtained for unaffected subjects marked *, but are not given to preserve confidentiality. Under each symbol is listed the confirmed diagnosis (Co=colorectal cancer, Ut $=$ uterine cancer, Ov=ovarian cancer) and age at diagnosis. 
Table 2 Multipoint lod scores at hMSH2 and hMLH1 in 14 HNPCC families (see text for details of groups). The posterior probabilities of linkage to $h M S H 2$ or hMLH1 were calculated according to the best fitting model (54\% families resulting from $h M S H 2$ and $46 \%$ from $h M L H 1$ ).

\begin{tabular}{|c|c|c|c|c|c|}
\hline \multirow[b]{2}{*}{ Group } & \multirow[b]{2}{*}{ Family } & \multicolumn{2}{|l|}{$h M S H 2$} & \multicolumn{2}{|l|}{$h M L H 1$} \\
\hline & & Lod score & $\begin{array}{l}\text { Posterior probability } \\
\text { of linkage }\end{array}$ & Lod score & $\begin{array}{l}\text { Posterior probability } \\
\text { of linkage }\end{array}$ \\
\hline A & C001 & 1.3 & 1.00 & $-2 \cdot 23$ & 0.00 \\
\hline A & $\mathrm{C} 002$ & $1 \cdot 16$ & 1.00 & -3.53 & 0.00 \\
\hline A & $\mathrm{C} 004$ & 1.52 & 1.00 & $-5 \cdot 56$ & 0.00 \\
\hline A & $\mathrm{C} 003$ & $1 \cdot 11$ & 1.00 & -2.98 & 0.00 \\
\hline A & C016 & 1.54 & 1.00 & $-3 \cdot 46$ & 0.00 \\
\hline A & C015 & 1.01 & 1.00 & $-2 \cdot 88$ & 0.00 \\
\hline B & C012 & $-3 \cdot 3$ & 0.00 & $1 \cdot 2$ & 1.00 \\
\hline B & $\mathrm{C} 014$ & $-3 \cdot 46$ & 0.00 & 1.35 & 1.00 \\
\hline B & C009 & $-3 \cdot 39$ & 0.00 & 1.38 & 1.00 \\
\hline C & C006 & 0.01 & 0.45 & $0 \cdot 17$ & 0.55 \\
\hline C & C008 & -0.37 & $0 \cdot 20$ & 0.30 & 0.80 \\
\hline C & $\mathrm{C} 007$ & $-0 \cdot 18$ & 0.80 & -0.7 & 0.20 \\
\hline C & C010 & -0.87 & 0.08 & 0.27 & 0.92 \\
\hline C & C011 & -1.36 & 0.01 & 0.69 & 0.99 \\
\hline
\end{tabular}

available for analysis. Four families belonged to group C (C007, C008, C010, C011) suggesting that susceptibility to colorectal cancer in these families was caused by a mutation in a mismatch repair gene. In addition, microsatellite instability was detected in a colorectal cancer from a family (C004) with MuirTorre syndrome.

\section{Discussion}

Although no single family gave a lod score of $>3$ at hMSH2 or hMLH1, six families were likely to be linked to hMSH 2 and three families to hMLH1. This interpretation is supported by exclusion of linkage to hMLH1 in those classified as probably being linked to $\mathrm{hMSH} 2$ and exclusion of linkage to $\mathrm{hMSH} 2$ in families with lod scores $>1$ at hMLH1. Our data would suggest that in the population studied most HNPCC families will have mutations in hMSH 2 or hMLH 1 and that mutations in other candidate HNPCC genes probably account for a minority of cases. Although further data are needed to substantiate these preliminary conclusions it is clear that there are geographical variations in the genetic epidemiology of HNPCC. In addition to the high frequency of hMLH1 families in Finland, ${ }^{1618}$ Lindblom et $a l^{32}$ reported linkage to hMLH1 in two Swedish kindreds and excluded linkage to chromosome $2 \mathrm{p} 21$ and $3 \mathrm{p} 21$ (that is, hMSH2 and hMLH1 respectively) in a third kindred. In a study of seven Canadian families, Green $e$ al $^{33}$ detected linkage to hMSH2 in two, excluded linkage to $\mathrm{hMSH} 2$ in three, and obtained indeterminate results in the remaining two families. We did not identify any families in which linkage to hMSH 2 and hMLH1 could be excluded suggesting that germline mutations in hPMS1 and hPMS 2 will probably account for a minority of HNPCC cases in the population studied. We note that a recent linkage study comprising 13 large HNPCC families from North America, Finland, and New Zealand reached a similar conclusion. ${ }^{34}$ The high incidence of hMLH1 linked families in Finland appears to result from a founder effect; however, we did not find a shared haplotype among our hMSH 2 or hMLH1 linked families.
The ability to identify the most likely candidate HNPCC gene for each family would facilitate the detection of germline mutations. Although HNPCC families have been divided into Lynch 1 and Lynch 2 subgroups, the classification of individual families is frequently not clear cut and does not appear to correlate with the results of molecular genetic analysis. Nevertheless further research is required to define the molecular basis of phenotypic variation in HNPCC. Although Muir-Torre syndrome is sometimes distinguished from a Lynch 2 phenotype, we and Honchel et $a l^{25}$ also found microsatellite instability in tumours from MuirTorre kindreds. In addition, Hall et al ${ }^{35}$ found linkage to hMSH2 in two families with MuirTorre syndrome, suggesting that the two disorders can be allelic. It is of interest that the Muir-Torre family we investigated was also linked to hMSH2, but Green et $a l^{33}$ excluded linkage to hMSH2 in a Canadian Muir-Torre kindred suggesting that this phenotype is not exclusively caused by mutations in hMSH 2 .

Although family linkage studies can provide information on the genetic epidemiology of HNPCC, an unsuitable family structure or unavailability of DNA from relatives who have died limits the number of families that can be investigated by genetic linkage analysis. In the presence of marked locus heterogeneity, few families are extensive enough to allow genetic linkage studies to be used for accurate presymptomatic diagnosis. Furthermore the presence of phenocopies (relatives with sporadic colorectal cancer) may further complicate the interpretation of genetic linkage studies, although investigation for microsatellite instability may help to distinguish HNPCC from sporadic colorectal tumours. ${ }^{31}$ Consequently the clinical application of molecular genetic diagnosis of HNPCC is likely to be based on direct mutation detection. The most efficient strategy will depend on the results of further molecular studies in the relevant population.

We thank the Cancer Research Campaign (CRC) for financial support and Dr Bert Vogelstein for details of CA5. We are indebted to Professor Tim Bishop for performing formal heterogeneity analysis. We are grateful to the many colleagues who have provided us with access to families, and to the patients and relatives who took part in this study. 
1 Houlston RS, Murday V, Harocopos C, Williams CB, Slack J. Screening and genetic counselling for relatives of patients with colorectal cancer in a family cancer clinic. $B M \mathcal{F} 1990$; 301:366-8.

2 Kinzler KW, Nilbert MC, Vogelstein B, et al. Identification of a gene located at chromosome $5 \mathrm{q} 21$ that is mutated in of a gene located at chromosome 5q21 that is
colorectal cancers. Science 1991;251:1366-70.

3 Nishisho I, Nakamura Y, Miyoshi Y, et al. Mutations of chromosome 5q21 genes in FAP and colorectal cancer chromosome 5q21 genes in FAP

4 Groden J, Thliveris A, Samowitz W, et al. Identification and characterization of the familial adenomatous polyposis coli gene. Cell 1991;66:589-600.

5 Nagase H, Miyoshi Y, Hirii A, et al. Screening for germine mutations in familial adenomatous polyposis (FAP) patients: 61 new patients and a summary of 150 unrelated patients. Mutat Res 1992;1:467-73.

6 Vasen HF, Offerhaus GJ, den Hartog Jager FC et al. The tumour spectrum in hereditary non-polyposis colorectal cancer: a study of 24 kindreds in the Netherlands. Int $\mathcal{F}$ Cancer 1990;46:31-4.

7 Lynch HT, Lanspa S, Smyrk T, Bowman B, Watson P, Lynch J. Hereditary nonpolyposis colorectal cancer (Lynch syndromes I \& II). Genetics, pathology, natural history, and cancer control. Part I. Cancer Genet Cytogenet 1991; 53:143-60.

8 Lynch HT, Lynch JF. The Lynch syndromes. Curr Opin Oncol 1993;5:687-96.

9 Hall NR, Williams AT, Murday VA, Newton JA, Bishop DT. Muir-Torre syndrome: a variant of the cancer family syndrome. $¥$ Med Genet 1994;31:627-31.

10 Peltomaki P, Sistonen P, Mecklin JP, et al. Evidence that the MCC-APC gene region in 5q21 is not the site for susceptibility to hereditary nonpolyposis colorectal carcinoma. Cancer Res 1992;52:4530-3.

11 Peltomaki P, Aaltonen LA, Sistonen P, et al. Genetic mapping of a locus predisposing to human colorectal cancer. ping of a locus predisposing

12 Aaltonen LA, Peltomaki P, Leach FS, et al. Clues to the pathogenesis of familial colorectal cancer. Science 1993; 260:810-12.

13 Fishel R, Lescoe MK, Rao MRS, et al. The mutator gene homolog MSH2 and its association with hereditary nonpolyposis colorectal cancer. Cell 1993;75:1027-38.

14 Leach FS, Nicolaides NC, Papadopoulos N, et al. Mutation of a mutS homolog in hereditary nonpolyposis colorectal cancer. Cell 1993;75:1215-25.

15 Bronner CE, Baker SM, Morrison PT, et al. Mutation in the DNA mismatch repair gene homologue hMLH1 is associated with hereditary non-polyposis colon cancer Nature 1994;368:258-61.

16 Papadopoulos N, Nicolaides NC, Wei Y-F, et al. Mutation of a mutL homolog in hereditary colon cancer. Science 1994;263:1625-9.

17 Nicolaides NC, Papadopoulos N, Liu B, et al. Mutations of two PMS homologues in hereditary non-polyposis colon cancer. Nature 1994;371:75-80.

18 Nystrom-Lahti $M$, Sistonen $P$, Mecklin J-P, et al. Close linkage to chromosome $3 p$ and conservation of ancestral founding haplotype in hereditary nompolyposis colorectal founding haplotype in hereditary nonpolyposis colorectal

19 Weissenbach J, Gyapay G, Dib C, et al. A second generation linkage map of the human genome. Nature 1992;359: 794-801.

20 Gyapay G, Monsette J, Vignal A, et al. The 1993-1994 Genethon human genetic linkage map. Nature Genet 1994; 7:246-339.

21 Jones $\mathrm{MH}$, Yamakawa $\mathrm{K}$, Nakamura $\mathrm{Y}$. Isolation and characterisation of 19 dinucleotide repeat polymorphisms on

22 Vasen HF, Mecklin JP, Khan PM, Lynch HT. The International Collaborative Group on Hereditary NonPolyposis Colorectal Cancer (ICG-HNPCC). Dis Colon Rect 1991;34:424-5.

23 Muir EG, Yates Bell AJ, Barlow KA. Multiple primary carcinomata of the colon, duodenum and larynx associated with kerato-acanthoma of the face. $B r \mathcal{F}$ Surg 1967;54: 191-5.

24 Torre D. Multiple sebaceous tumours. Arch Dermatol 1968; 98:549-51.

25 Honchel R, Halling KC, Schaid DJ, Pittelkow M, Thibodeau S. Microsatellite instability in Muir-Torre syndrome. Cancer Res 1994;54:1159-63.

26 Spirio L, Olschwang S, Groden J, et al. Alleles of the APC gene: an attenuated form of familial polyposis. Cell 1993 75:951-7.

27 Crossey PA, Maher ER, Jones $\mathrm{MH}$, et al. Genetic linkage between von Hippel-Lindau disease and three microsatellite polymorphisms refines the localisation of the VHL locus. Hum Molec Genet 1993;2:279-82.

28 Foster K, Crossey PA, Cairns P, et al. Molecular genetic investigation of sporadic renal cell carcinoma: analysis of allele loss on chromosomes $3 \mathrm{p}, 5 \mathrm{q}, 11 \mathrm{p}, 17$ and $22 . \mathrm{Br} f$ Cancer 1994;69:230-4.

29 Spirio L, Nelson L, Ward K, Burt R, White R, Leppert M. A CA-repeat polymorphism close to the adenomatous M. A CA-repeat polymorphism close to the adenomatous
polyposis coli (APC) gene offers improved diagnostic testing for familial APC. Am $¥$ Hum Genet 1993;52: testing for

30 Smith SA, Easton DF, Evans DG, Ponder BAJ. Allele losses in the region $17 \mathrm{q} 12-21$ in familial breast and ovarian cancer involve the wildtype chromosome. Nature Gene 1992;2:128-31.

31 Aaltonen LA, Peltomaki P, Mecklin JP, et al. Replication errors in benign and malignant tumours from hereditary nonpolyposis colorectal cancer patients. Cancer Res 1994; 54:1645-8.

32 Lindblom A, Tannergard P, Werelius B, Nordenskjold M. Genetic mapping of a second locus predisposing to hereditary non-polyposis colon cancer. Nature Genet 1993;5: 279-82.

33 Green RC, Narod SA, Morasse J, et al. Hereditary nonpolyposis colon cancer: analysis of linkage to $2 \mathrm{p} 15-16$ places the COCA1 locus telomeric to D2S123 and reveals genetic heterogeneity in seven Canadian families. $A m \mathcal{F}$ Hum Genet 1994;54:1067-77.

34 Nystrom-Lahti M, Parsons R, Sistonen P, et al. Mismatch repair genes on chromosomes $2 p$ and $3 p$ account for a major share of hereditary nonpolyposis colorectal cancer families evaluable by linkage. Am f Hum Genet 1994;55: 659-65.

35 Hall NR, Murday VA, Chapman P, et al. Genetic linkage in Muir-Torre syndrome to the same chromosomal region as cancer family syndrome. Eur f Cancer 1994;30A:1 80-2. 